\title{
Efficacy of K-Humate, Compost and Biofertilizer Application as Well as Cutting Number on Yield and Quality of Stevia (Stevia rebaudianaBertoni) as Natural Sweetener
}

Rashwan, Basma R.A. ${ }^{1}$; Reem M. Abd-El Raouf ${ }^{2}$; Nagwa R. Ahmed ${ }^{3}$ and H. Ferweez ${ }^{4}$

${ }^{1}$ Soil, Water and Environ. Res. Inst., A.R.C., Giza, Egypt.

${ }^{2}$ Horti. Res. Inst., Agric. Res. Centre, Giza, Egypt.

${ }^{3}$ Field Crops Rese. Inst., A.R.C., Giza, Egypt.

${ }^{4}$ Food Sci. and Techno. Dept., Fac. Agric. New Valley, Assiut University, Egypt.

Received on: 6/11/2016

Accepted for publication on: 15/11/2016

\begin{abstract}
Stevioside is natural sweetener isolated from the leaves of plant stevia and it is up to 300 times sweetener than sucrose, since it is a sweetener with no caloric value and with proven non-toxic effect on human health. Steviol glycosides are used as a sweetener in many industrial foods, such as soft drinks or fruit juices. So, two field experiments were conducted at Mallawi Agricultural Research Station, El-Minia Governorate during 2014 and 2015 seasons to deduce the effect of different sources of nutrient, i.e. Control $\left(80 \mathrm{~kg} \mathrm{~N} \mathrm{fed}^{-1}\right)$, K-humate $+\left(40 \mathrm{~kg} \mathrm{~N} \mathrm{fed}^{-1}\right)$, biofertilizer $+\left(40 \mathrm{~kg} \mathrm{~N} \mathrm{fed}^{-1}\right)$ and compost $\left.+\left(40 \mathrm{~kg} \mathrm{~N}^{-1} \mathrm{fed}^{-1}\right)\right]$ and number of cutting, i.e. $1^{\text {st }}, 2^{\text {nd }}$ and $3^{\text {rd }}$ cutting on yield and quality of stevia (Stevia rebaudianaBertoni) under Middle Egypt conditions. The obtained data pointed out that different sources of nutrient had a significant effect on plant height, fresh plant weight, dry plant weight, fresh leaves weight/plant, dry leaves weight/plant, N, P and K \% of stevia leaf, fresh biomass yield, dry biomass yield , fresh leaves yield, dry leaves yield and fresh stem yield, total stevioside \% (St $\%$, rebaudioside $\mathrm{A} \%(\mathrm{Rb} \%)$, stevioside yield and rebaudioside $\mathrm{A}$ yield of stevia in two growing seasons.

The studied cutting number of stevia had a significant influence on plant height, fresh plant weight, dry plant weight, fresh leaves weight/plant, dry leaves weight/plant, dry leaves weight: dry stem weight, $\mathrm{P} \%$ of stevia leaf, fresh biomass yield, dry biomass yield, fresh leaves yield, dry leaves yield and fresh stem yield and dry stem yield of stevia, rebaudioside $\mathrm{A} \%$, total stevioside yield $(\mathrm{kg} / \mathrm{fed})$ and rebaudioside A yield $(\mathrm{kg} / \mathrm{fed})$ of stevia rebaudiana in two growing seasons. From the present study, it may be concluded that the application of compost at $2.0 \mathrm{ton} / \mathrm{fed}+\left(40 \mathrm{~kg} \mathrm{~N}\right.$ fed-1) with $3^{\text {rd }}$ cutting was the best treatment for improving the yield and quality of stevia (Stevia rebaudianaBertoni) and is advisable because it is achieved the highest value of rebaudioside $\mathrm{A}(102.80 \mathrm{~kg} / \mathrm{fed})$ of stevia. This helps in reducing the great gap in sugar production, which amounted to 0.7 million tons between production and sugar consumption at the national level production under the experimental conditions.
\end{abstract}

Keywords: Stevia, source of nutrient, number of cutting, stevioside \% and rabaudioside A. 


\section{Introduction}

Stevioside is natural sweetener isolated from the leaves of plant stevia and it is up to 300 times sweetener than sucrose, since it is a sweetener with no caloric value and with proven non-toxic effect on human health. Steviol glycosides are used as a sweetener in many industrial foods, such as soft drinks or fruit juices.

Stevia is grown commercially in many parts of Brazil, Paraguay, Uruguay, Central America, Israel, Thailand and China. It has been used for thousands of years as a source of intensively sweet-tasting compounds. The steviol glycosides, eight types of steviol glycosides in leaves were identified, stevioside, rebaudioside A, B, C, D, E and dulcoside A and B. Stevioside has been used as intensive more energetic sweeteners in many countries of South America and Asia. Steviosides had non- caloric property. Stevia is a major source of high potency sweetener in food market (Patil, 2010).

Fertilizers play an important role in increasing crop production. Its influence vegetative and reproductive phase of plant growth. In the developing countries such as Egypt, the increasing prices of fertilizers is affecting the poor farmers. Nutrient requirements of stevia are low to moderate because this crop is adaptable to poor- quality soils. Composts are prepared by biological degradation of plant and animal residues under controlled and aerobic conditions. virmicompost is described as biooxidation and stabilization of organic material involving the joint action of earthworms and mesoplilic microorganisms (Patil, 2010).
Bio-fertilizers are formulations of beneficial microorganisms, such as Bacillus megaterium, which upon application can increase the availability of nutrients by their biological activity and help to improve the soil health. Biofertilizers are useful substitutes to inorganic fertilizers which improves the soil quality. One of the recent achievements is the use of biofertilizer which retards nitrification for sufficiently longer time and increases the soil fertility. Integrated nutrient management using biofertilizer is found to increase yield of stevia (Patil, 2010). Gupta, et al. (2011) indicated that phosphorussolubilizing bacteria treatment of stevia increased the growth and stevioside ( $\mathrm{St}$ ) and rebaudioside $\mathrm{A}(\mathrm{Rb})$ contents of plants.

The climatic conditions in most parts of Egypt are quite favorable for stevia cultivation. Hence, this work carried out to assess the changes in yield and quality of stevia (Stevia rebaudianaBertony) as affected by different sources of nutrient and number of cutting under Middle Egypt conditions.

\section{Material and Method}

Two field experiments were conducted at Mallawi Agricultural Research Station, El-Minia Governorate (latitude of $27.43^{\circ} \mathrm{N} \&$ longitude of $30.50^{\circ}$ E) during 2014 and 2015 seasons to deduce the effect of different sources of nutrient (Control $\left(80 \mathrm{~kg} \mathrm{~N} \mathrm{fed}^{-1}\right), \mathrm{K}$-humate $+40 \mathrm{~kg} \mathrm{~N}$ $\mathrm{fed}^{-1}$, biofertilizer $+40 \mathrm{~kg} \mathrm{~N}$ fed $^{-1}$ and compost $+40 \mathrm{~kg} \mathrm{~N} \mathrm{fed}^{-1}$ ]) and number of cutting, i.e. $1^{\text {st }}, 2^{\text {nd }}$ or $3^{\text {rd }}$ cutting on yield and quality of stevia (Stevia rebaudianaBertony). 
Biofertilizer (Azotobacterchroococcumand Bacillus megaterium) were provided from Microbiological Unit, Agriculture Research Center, Giza, Egypt. Compost was used by rate of 2 ton / fed in this work; it was incorporated 3 weeks before transplanting stevia in the plots and composed it as in Table 2. K-humatewas used at rate 2.0 liter/fed at twice, the first : the roots were soaked in solution (K-humate + water) before the transplanting in the $1^{\text {st }}$ cutting, while in the phase of $2^{\text {nd }}$ or $3^{\text {rd }}$ cutting, the seedling were treated by K-humate as foliar(1.0 liter/100 water liters/fed). The second: the seedling were treated by $\mathrm{K}$-humate as foliar(1.0 liter/100 water liters/fed) before irrigation and after 30 days from the first in the phase of $1^{\text {st }}, 2^{\text {nd }}$ or $3^{\text {rd }}$ cutting.

A split-plot design in three replications was used. The different sources of nutrient [Control $(80 \mathrm{~kg} \mathrm{~N}$ $\left.\mathrm{fed}^{-1}\right)$, K-humate $+\left(40 \mathrm{~kg} \mathrm{~N}\right.$ fed $\left.^{-1}\right)$, biofertilizer $\left.+(40 \mathrm{~kg} \mathrm{~N} \mathrm{fed})^{-1}\right)$ and compost $\left.+\left(40 \mathrm{~kg} \mathrm{~N} \mathrm{fed}^{-1}\right)\right]$ were allocated in the main plots and the number of cutting were randomly distributed in the sub-plots.

The seedlings of stevia, Spanish cultivar, were purchased from the sugar crops research institute and grown in the experimental farm of Mallawi Agric., Res. Station, on the beds $(120 \mathrm{~cm})$ at the two sides. Stevia seedlings were transplanted at a spacing of $35 \times 60 \mathrm{~cm}$ at $25^{\text {th }}$ and $23^{\text {th }}$ March 2014 and 2015, respectively. It is perennial plant. Stevia plants was cut or harvested just prior to flowering when the concentration of steviol glycoside in the leaves is at its maximum, since glycoside synthesis is reduced at or just before flower- ing (Kumar, et al. 2014), leaving 10 $\mathrm{cm}$ up to ground level, periodically at 90 days ( $1^{\text {st }}$ cutting), 140 days $\left(2^{\text {nd }}\right.$ cutting) and 190 days ( $3^{\text {rd }}$ cutting)of planting. Growth of stevia plants stops under the low temperatures, i.e. in winter season.

Nitrogen fertilizer as $\mathrm{NH}_{4} \mathrm{NO}_{3}$ was added at $80 \mathrm{~kg} \mathrm{Nfed}^{-1}$, Controlor $40 \mathrm{~kg} \mathrm{~N} \mathrm{fed}{ }^{-1}$ of control plus different sources of nutrient (K-humate, compostorbiofertilizer) were added in two equal doses, the first and the second before the second and third irrigation, respectively.

Phosphorus and potassium fertilizers were applied once before transplanting, (Phosphorus fertilizer the rate of $150 \mathrm{~kg}$ calcium super phosphate $\left(15.5 \% \mathrm{P}_{2} \mathrm{O}_{5}\right)$ and potassium fertilizer the rate of $50 \mathrm{~kg}$ Potassium Sulphate $\left(48 \% \mathrm{~K}_{2} \mathrm{O}\right)$. Seedlings of stevia were soaked before transplanting with the biofertilizers ((Azotobacterchroococcum and $\mathrm{Ba}$ cillus megaterium), were provided from Microbiological Unit, Agriculture Research Center, Giza, Egypt. the number of bacteria reached about $1 \times 10^{8} \mathrm{cell} / \mathrm{ml}$ and then, the inocula were used for inoculation of seedlings) and the biofertilizers was added with irrigation water two times (5 Liters per fed), the first was on after 30 days from planting seedlings and the second was after two weeks from the first.

Data recorded: Five plants of stevia / plots were selected randomly and cut at the ground level before flowering to measure the following parameters:

\section{A. Vegetative traits :}

1- Plant height $(\mathrm{cm})$.

2- Fresh plant weight (g) 
3- Dry plant weight (g), (the plants were dried in air oven at $\left.60^{\circ} \mathrm{C}\right)$.

4- Fresh leaves weight (g)/plant

5- Dry leaves weight $(\mathrm{g}) /$ plant

6- Dry leaves weight: dry stem weight.

\section{B. Leaves nutrient status:}

Stevia leaves samples were done at 15 days interval followed by fertilizer treatments in the third and fourth leaf from the top to determine N P K of leaves collected from different treatments. Leaves dried in a forced oven at $60^{\circ} \mathrm{C}$ till constant of weight; ground to a fine powder and sub sample of $0.2 \mathrm{gm}$. was wet

Table 1. Some physical and chemical properties of the experimental soil.

\begin{tabular}{|c|c|c|}
\hline Properties & 2014 & 2015 \\
\hline \multicolumn{3}{|c|}{ Particle size distribution (\%) } \\
\hline Sand $(\%)$ & 8.03 & 8.11 \\
\hline Silt (\%) & 53.55 & 52.91 \\
\hline Clay $(\%)$ & 38.43 & 38.98 \\
\hline Soil texture & \multicolumn{2}{|c|}{ Silty clay loam } \\
\hline Organic matter (\%) & 1.14 & 1.15 \\
\hline $\mathrm{pH}$ soil - water suspension ratio $(1: 2.5)$ & 8.20 & 8.15 \\
\hline EC(dsm-1)soil-water extract ratio (1:5) & 1.24 & 1.26 \\
\hline \multicolumn{3}{|c|}{ Soluble cations $(\mathrm{meq} / \mathrm{L})$} \\
\hline $\mathrm{Ca}^{++}$ & 7.35 & 7.15 \\
\hline $\mathrm{Mg}^{++}$ & 2.13 & 2.16 \\
\hline $\mathrm{Na}^{+}$ & 3.21 & 3.43 \\
\hline $\mathrm{K}^{+}$ & 0.20 & 0.25 \\
\hline \multicolumn{3}{|c|}{ Soluble anions (meq/L) } \\
\hline $\mathrm{CO}_{3}^{--}$ & --- & --- \\
\hline $\mathrm{HCO}^{-}$ & 3.20 & 3.44 \\
\hline $\mathrm{Cl}^{-}$ & 4.14 & 4.08 \\
\hline $\mathrm{SO}_{4}^{--}$ & 5.55 & 5.47 \\
\hline \multicolumn{3}{|c|}{ Available nutrients $\left(\mathrm{mg} \mathrm{kg}^{-1}\right)$} \\
\hline Available N (ppm) & 18.20 & 18.31 \\
\hline Available P (ppm) & 7.67 & 7.71 \\
\hline Available K (ppm) & 155.50 & 155.82 \\
\hline
\end{tabular}

digested using sulphuric-perchloric acid mixture (1:1) as described by A.O.A.C. (2005), to determine the total $\mathrm{N}, \mathrm{P}$ and $\mathrm{K}$ in the acidic extract as follows:

- Total nitrogen (\%) was determined by Kjeldahl method according to Jackson, (1967).

- Total Potassium (\%) was determined using the flame photometer as described by Jackson, (1967).
- Total phosphorus (\%) as described by Jackson, (1967).

Soil analysis was done according to the method described by Jackson (1967). The Physical and chemical properties of the experimental soil in Table I. 
Table 2 a Some characteristics of composted crop residues (CCR)

\begin{tabular}{|c|c|c|c|c|c|c|c|c|c|c|c|c|}
\hline \multirow[t]{2}{*}{ Properties } & \multirow[t]{2}{*}{$\begin{array}{l}\text { OM } \\
(\%)\end{array}$} & \multirow[t]{2}{*}{$\begin{array}{c}\text { Organic } \\
\text { carbon } \\
(\%)\end{array}$} & \multirow{2}{*}{$\begin{array}{c}\text { pH soil - } \\
\text { water sus- } \\
\text { pension } \\
\text { ratio } \\
(1: 10)\end{array}$} & \multirow{2}{*}{$\begin{array}{c}\text { E.C soil- } \\
\text { water ex- } \\
\text { tract } \\
(1: 10) . \\
(\mathrm{dS} / \mathrm{m} \backslash \mathbf{1})\end{array}$} & \multirow[t]{2}{*}{ C:N } & \multicolumn{3}{|c|}{$\begin{array}{l}\text { Total macro- } \\
\text { nutrients }(\%)\end{array}$} & \multicolumn{3}{|c|}{$\begin{array}{l}\text { Total micro- } \\
\text { nutrients } \\
\text { (ppm) }\end{array}$} & \multirow{2}{*}{\begin{tabular}{|c|}
$\begin{array}{c}\text { Weight } \\
\text { of one } \\
\mathbf{m}^{3} \\
(\mathrm{~kg})\end{array}$ \\
\end{tabular}} \\
\hline & & & & & & $\mathbf{N}$ & $\mathbf{P}$ & $\mathbf{K}$ & $\mathrm{Zn}$ & $\mathrm{Fe}$ & Mn & \\
\hline Values & 32.75 & 19.25 & 7.85 & 6.9 & 11.6:1 & 0.87 & 0.22 & 0.85 & 54 & 810 & 204 & 500 \\
\hline
\end{tabular}

Table $2_{b}$. Some characteristics of K- Humate

\begin{tabular}{|l|c|c|c|c|c|c|c|c|}
\hline properties & Humic acid & Volvic acid & $\mathrm{K}$ & $\mathrm{P}$ & $\mathrm{Fe}$ & $\mathrm{Zn}$ & $\mathrm{Mn}$ & $\mathrm{Mg}$ \\
\hline Values (\%) & 10 & 1 & 2.5 & 1 & 1 & 0.5 & 0.5 & 2 \\
\hline
\end{tabular}

\section{Yields:}

Stevia plants of inner two ridges for each plot were harvested or cut from the bottom, leaving $10 \mathrm{~cm}$ up to ground level and weighed and converted for $\mathrm{kg} /$ fed to determine:

1. Fresh biomass yield in $\mathrm{kg} / \mathrm{fed}$,

2. Dry biomass yield in $\mathrm{kg} / \mathrm{fed}$, (the samples of stevia plants were dried in a hot-air oven at $60^{\circ} \mathrm{C}$ ).

3. Fresh leaves yield in $\mathrm{kg} / \mathrm{fed}$

4. Dry leaves yield in $\mathrm{kg} / \mathrm{fed}$

5. Fresh stem yield in $\mathrm{kg} / \mathrm{fed}$

6. Dry stem yield in $\mathrm{kg} / \mathrm{fed}$

\section{Quality traits of stevia:}

Quality traits of stevia in two field experiments were determined as follows:

1. Stevioside \% of dry stevia leaves (St \%) was estimated using the method described by A.O.A.C. (2005).

2. Rebaudioside $\mathrm{A} \%(\mathrm{Rb} \%)$ of dry stevia leaves was estimated using the method described by A.O.A.C. (2005).

3. Steviosideyield (St yield) of dry stevia leaves ( $\mathrm{kg} / \mathrm{fed}$ ) was calculated by the formula as follows:

St yield $(\mathrm{kg} / \mathrm{fed})=$ dry stevia leaves yield $(\mathrm{kg} / \mathrm{fed}) \mathrm{X}$ Stevioside \% of dry leaves.
4. Rebaudioside A yield ( $\mathrm{Rb}$ yield) of dry stevia leaves $(\mathrm{kg} / \mathrm{fed})$ was calculated by the formula as follows:

$\mathrm{Rb}$ yield $(\mathrm{kg} / \mathrm{fed})=$ dry stevia leaves yield $(\mathrm{kg} / \mathrm{fed}) \mathrm{X}$ Rebaudioside $\mathrm{A} \%$ of dry leaves.

\section{Sweet glycosides extraction:}

Stevia leaves were collected from different treatments at harvest. Leaves were dried at $60 \mathrm{OC}$ in hot air oven for $48 \mathrm{~h}$. Hundred milligrams of air-dried powdered plant material (leaves) of stevia was macerated in methanol $(10 \mathrm{ml})$ overnight and filtered. Plant material was re-extracted with same solvent twice $(5 \mathrm{ml}$ each time) for $3 \mathrm{~h}$ each. theextractants were pooled together and concentrated up to dryness under reduced pressure. After defatting with nhexane $(2 \mathrm{ml})$ thrice and vacuum drying, the extract was dissolved in 10 $\mathrm{ml}$ of HPLC grade acetonitrile and water (80:20) mobile phase degassed for $5 \mathrm{~min}$. and filtered through 0.45 $\mu \mathrm{m}$ filter. The filtrated was used for HPLC analysis. Standard stock solutions $(1 \mathrm{mg} / 2 \mathrm{ml})$ of standards of stevioside and rebaudioside A contents were calculated through highperformance liquid chromatography (HPLC). 
Data collected were subjected to Analysis of Variance (ANOVA). The proper statistical of all data was carried out according. Differences among treatments were evaluated by the least significant difference test (LSD) according to procedure out lined by Gomez \& Gomez (1984). Significant of differences was defined at 5 per cent level.

\section{Results and Discussion}

\section{I-Vegetative traits:}

It could be clarified from the results in Tables (3-8) that source of nutrients had a significant effect on plant height $(\mathrm{cm})$, fresh plant weight, dry plant weight, fresh leaves weight/plant, dry leaves weight/plant of stevia rebaudianaBertoni in two growing seasons, except dry leaves: dry stem in the $1^{\text {st }}$ season. The lowest values of plant height $(48.67 \mathrm{~cm})$, fresh plant weight (624.33g), dry plant weight $(212.67 \mathrm{~g})$, fresh leaves weight $(230.61 \mathrm{~g}) /$ plant, dry leaves weight $(75.45 \mathrm{~g}) /$ plant and dry leaves weight: dry stem weight fresh (1.17) was recorded with control(80 $\mathrm{kg} \mathrm{N}$ $\mathrm{fed}^{-1}$ ) treatment. While, compost + $50 \%$ of the control treatment scored the highest values for plant height, fresh plant weight, dry plant weight, fresh leaves weight/plant and dry leaves weight/plant traits $(62.52 \mathrm{~cm}$, $670.28 \mathrm{~g}, 250.45 \mathrm{~g}, 274.67 \mathrm{~g}$, and $93.95 \mathrm{~g}$ ) of stevia. This result might be due to that the release of nutrients from compost and their absorption by plants and remineralization of immobilized $\mathrm{N}$ require time, which has become imperative to sustain high nutrient supply for greater productivity. However, application of control ( 80 $\mathrm{kg} \mathrm{N}$ fed $^{-1}$ ) treatment alone might meet the lower nutrient demand . Similar data was recorded with those reported by Das et al. (2009); Khaled \& Fawy (2011) and Kumar, et al. (2012 and 2013) who indicated biomass yield of stevia increased with application of compost over control (without biofertilizer or compost).

Table 3. Effect of different sources of nutrient and number of cutting on plant height (cm) of stevia plant during 2014 and 2015 seasons.

\begin{tabular}{|c|c|c|c|c|c|c|c|c|c|}
\hline \multirow{3}{*}{ Source of nutrient (A) } & \multicolumn{4}{|c|}{2014 season } & \multicolumn{4}{|c|}{2015 season } & \multirow{3}{*}{$\begin{array}{c}\text { Overall } \\
\text { mean }\end{array}$} \\
\hline & \multicolumn{8}{|c|}{ Number of cutting (B) } & \\
\hline & $\begin{array}{c}1^{\text {st }} \\
\text { cutting }\end{array}$ & $\begin{array}{c}2^{\text {nd }} \\
\text { cutting }\end{array}$ & $\begin{array}{c}3^{\text {rd }} \\
\text { cutting }\end{array}$ & Mean & $\begin{array}{c}1^{\text {st }} \\
\text { cutting }\end{array}$ & $\begin{array}{c}2^{\text {nd }} \\
\text { cutting }\end{array}$ & $\begin{array}{c}3^{\text {rd }} \\
\text { cutting }\end{array}$ & Mean & \\
\hline Control $\left(80 \mathrm{~kg} \mathrm{~N}\right.$ fed $\left.^{-1}\right)$ & 37.67 & 44.67 & 60.00 & 47.44 & 39.00 & 47.67 & 63.00 & 49.89 & 48.67 \\
\hline K-Humate $+((50 \%$ of cont. $)$ & 39.40 & 48.67 & 63.67 & 50.58 & 61.33 & 61.00 & 77.67 & 66.67 & 58.62 \\
\hline Biofertilizer $+(50 \%$ of cont. $)$ & 41.20 & 58.53 & 66.00 & 55.24 & 61.67 & 60.28 & 71.67 & 64.54 & 59.89 \\
\hline Compost + (50\%of cont.) & 43.07 & 60.53 & 70.00 & 57.87 & 62.78 & 64.05 & 74.67 & 67.17 & 62.52 \\
\hline Mean & 40.33 & 53.10 & 64.92 & 52.78 & 56.19 & 58.25 & 71.75 & 62.06 & 57.78 \\
\hline $\begin{array}{cc}\text { LSD } & \text { A } \\
& \\
\text { BB } & \end{array}$ & & $\begin{array}{l}1 . \\
2 . \\
5 .\end{array}$ & $\begin{array}{l}46 \\
71 \\
42\end{array}$ & & & & $\begin{array}{l}3.27 \\
2.27 \\
4.55\end{array}$ & & \\
\hline
\end{tabular}


Table 4. Effect of different sources of nutrient and number of cutting onfresh plant weight (g) of stevia plant during 2014 and 2015 seasons.

\begin{tabular}{|c|c|c|c|c|c|c|c|c|c|}
\hline \multirow{3}{*}{ Source of nutrient (A) } & \multicolumn{4}{|c|}{2014 season } & \multirow{2}{*}{\multicolumn{4}{|c|}{$\begin{array}{lr} & 2015 \text { season } \\
\text { cutting (B) }\end{array}$}} & \multirow{3}{*}{$\begin{array}{c}\text { Overall } \\
\text { mean }\end{array}$} \\
\hline & \multicolumn{4}{|c|}{ Number of cutting (B) } & & & & & \\
\hline & $\begin{array}{c}1^{\text {st }} \\
\text { cutting }\end{array}$ & $\begin{array}{c}2^{\text {nd }} \\
\text { cutting }\end{array}$ & $\begin{array}{l}3^{\text {rd }} \text { cut- } \\
\text { ting }\end{array}$ & Mean & $\begin{array}{c}1^{\text {st }} \\
\text { cutting }\end{array}$ & $\begin{array}{c}2^{\text {nd }} \\
\text { cutting }\end{array}$ & $\begin{array}{l}3^{\text {rd }} \text { cut- } \\
\text { ting }\end{array}$ & Mean & \\
\hline Control $\left(80 \mathrm{~kg} \mathrm{~N}\right.$ fed $\left.^{-1}\right)$ & 577.33 & 632.33 & 648.67 & 619.44 & 586.67 & 642.33 & 658.67 & 629.22 & 624.33 \\
\hline K-Humate $+((50 \%$ of cont. $)$ & 587.33 & 640.67 & 668.67 & 632.22 & 619.33 & 659.33 & 696.33 & 658.33 & 645.28 \\
\hline $\begin{array}{l}\text { Biofertilizer }+(50 \% \text { of } \\
\text { cont. })\end{array}$ & 606.67 & 630.00 & 671.00 & 635.89 & 640.33 & 665.00 & 688.00 & 664.44 & 650.17 \\
\hline Compost $+(50 \%$ of cont. $)$ & 641.33 & 659.67 & 689.00 & 663.33 & 651.33 & 671.00 & 709.33 & 677.22 & 670.28 \\
\hline Mean & 603.17 & 640.67 & 669.33 & 637.72 & 624.42 & 659.42 & 688.08 & 657.31 & 647.52 \\
\hline $\begin{array}{r}\text { LSD A } \\
\mathbf{B} \\
\mathbf{A B}\end{array}$ & \multicolumn{4}{|c|}{10.04} & & & $\begin{array}{c}7.51 \\
7.61 \\
15.22\end{array}$ & & \\
\hline
\end{tabular}

Table 5. Effect of different sources of nutrient and number of cutting ondry plant weight (g) of stevia plant during during 2014 and 2015 seasons.

\begin{tabular}{|c|c|c|c|c|c|c|c|c|c|}
\hline \multirow{3}{*}{ Source of nutrient(A) } & \multicolumn{4}{|c|}{2014 season } & \multirow{2}{*}{\multicolumn{4}{|c|}{$\begin{array}{l}2015 \text { season } \\
\text { cutting }(B)\end{array}$}} & \multirow{3}{*}{$\begin{array}{c}\text { Overall } \\
\text { mean }\end{array}$} \\
\hline & \multicolumn{4}{|c|}{ Number of cutting (B) } & & & & & \\
\hline & $\begin{array}{c}1^{\mathrm{st}} \\
\text { cutting }\end{array}$ & $\begin{array}{l}2^{\text {nd }} \\
\text { cutting }\end{array}$ & $\begin{array}{l}3^{\text {rd }} \\
\text { cutting }\end{array}$ & Mean & $\begin{array}{c}1^{\mathrm{st}} \\
\text { cutting }\end{array}$ & $\begin{array}{l}2^{\text {nd }} \\
\text { cutting }\end{array}$ & $\begin{array}{l}3^{\text {rd }} \\
\text { cutting }\end{array}$ & Mean & \\
\hline Control $\left(80 \mathrm{~kg} \mathrm{~N} \mathrm{fed}^{-1}\right)$ & 188.67 & 203.67 & 231.33 & 207.89 & 197.67 & 213.33 & 241.00 & 217.44 & 212.667 \\
\hline K-Humate+((50\% of cont. $)$ & 193.00 & 206.00 & 237.00 & 212.00 & 224.00 & 240.00 & 261.00 & 241.67 & 226.834 \\
\hline $\begin{array}{l}\text { Biofertilizer }+(50 \% \text { of } \\
\text { cont.) }\end{array}$ & 204.67 & 219.67 & 239.00 & 221.11 & 239.33 & 263.33 & 275.33 & 259.22 & 240.167 \\
\hline Compost + (50\% of cont.) & 217.00 & 234.33 & 253.33 & 234.89 & 249.00 & 265.00 & 284.00 & 266.00 & 250.445 \\
\hline Mean & 200.83 & 215.92 & 240.17 & 218.97 & 227.42 & 245.42 & 265.42 & 246.09 & 232.528 \\
\hline $\begin{array}{lc}\text { LSD } & \text { A } \\
& \text { B } \\
& \text { AB }\end{array}$ & & & $\begin{array}{l}70 \\
22 \\
44\end{array}$ & & & & $\begin{array}{l}4.72 \\
3.05 \\
6.09\end{array}$ & & \\
\hline
\end{tabular}

Table 6. Effect of different sources of nutrient and number of cutting on freshleaves weight (g)/ plant ofstevia plant during 2014 and 2015 seasons.

\begin{tabular}{|c|c|c|c|c|c|c|c|c|c|}
\hline \multirow{3}{*}{ Source of nutrient (A) } & & 2014 & eason & & & 2015 & season & & \multirow{3}{*}{$\begin{array}{l}\text { Overal } \\
1 \text { mean }\end{array}$} \\
\hline & \multicolumn{8}{|c|}{ Number of cutting (B) } & \\
\hline & $\begin{array}{c}1^{\text {st }} \\
\text { cutting }\end{array}$ & $\begin{array}{l}2^{\text {nd }} \\
\text { cutting }\end{array}$ & $\begin{array}{l}3^{\text {rd }} \\
\text { cutting }\end{array}$ & Mean & $\begin{array}{c}1^{\text {st }} \\
\text { cutting }\end{array}$ & $\begin{array}{l}2^{\text {nd }} \\
\text { cutting }\end{array}$ & $\begin{array}{l}3^{\text {rd }} \\
\text { cutting }\end{array}$ & Mean & \\
\hline Control $\left(80 \mathrm{~kg} \mathrm{~N}\right.$ fed $\left.^{-1}\right)$ & 215.33 & 227.33 & 242.33 & 228.33 & 219.00 & 232.33 & 247.33 & 232.89 & 230.61 \\
\hline K-Humate+(50\%of cont.) & 218.00 & 230.00 & 246.67 & 231.56 & 243.00 & 262.33 & 275.67 & 260.33 & 245.95 \\
\hline Biofertilizer $+(50 \%$ of cont. $)$ & 222.67 & 250.67 & 269.33 & 247.56 & 257.33 & 280.33 & 294.00 & 277.22 & 262.39 \\
\hline Compost $+(50 \%$ of cont. $)$ & 243.00 & 267.67 & 279.33 & 263.33 & 264.67 & 289.33 & 304.00 & 286.00 & 274.67 \\
\hline Mean & 224.75 & 243.92 & 259.42 & 242.69 & 246.00 & 266.08 & 280.25 & 264.11 & 253.40 \\
\hline $\begin{array}{lc}\text { LSD } & \mathbf{A} \\
& \text { B } \\
& \text { AB }\end{array}$ & & $\begin{array}{l}0 . \\
1 . \\
3 .\end{array}$ & $\begin{array}{l}91 \\
86 \\
71\end{array}$ & & & & $\begin{array}{l}2.89 \\
1.96 \\
3.92\end{array}$ & & \\
\hline
\end{tabular}


Table 7. Effect of different sources of nutrient and number of cutting on dry leavesweight (g)/ plant of stevia plant during 2014 and 2015 seasons.

\begin{tabular}{|c|c|c|c|c|c|c|c|c|c|}
\hline \multirow{3}{*}{ Source of nutrient (A) } & \multicolumn{4}{|c|}{2014 season } & \multicolumn{4}{|c|}{2015 season } & \multirow[b]{3}{*}{$\begin{array}{c}\text { Overall } \\
\text { mean }\end{array}$} \\
\hline & \multicolumn{8}{|c|}{ Number of cutting (B) } & \\
\hline & $\begin{array}{c}1^{\text {st }} \\
\text { cutting }\end{array}$ & $\begin{array}{c}2^{\text {nd }} \\
\text { cutting }\end{array}$ & $\begin{array}{c}3^{\text {rd }} \\
\text { cutting }\end{array}$ & Mean & $\begin{array}{c}1^{\text {st }} \\
\text { cutting }\end{array}$ & $\begin{array}{c}2^{\text {nd }} \\
\text { cutting }\end{array}$ & $\begin{array}{c}3^{\text {rd }} \\
\text { cutting }\end{array}$ & Mean & \\
\hline Control $\left(80 \mathrm{~kg} \mathrm{~N} \mathrm{fed}^{-1}\right)$ & 64.67 & 75.00 & 81.33 & 73.67 & 67.67 & 78.00 & 86.00 & 77.22 & 75.45 \\
\hline K-Humate+((50\% of cont.) & 68.33 & 78.67 & 84.00 & 77.00 & 79.00 & 93.33 & 82.67 & 85.00 & 81.00 \\
\hline $\begin{array}{l}\text { Biofertilizer }+(50 \% \text { of } \\
\text { cont.) }\end{array}$ & 73.00 & 86.33 & 91.33 & 83.56 & 83.33 & 96.67 & 102.00 & 94.00 & 88.78 \\
\hline Compost $+(50 \%$ of cont. $)$ & 79.67 & 91.00 & 98.67 & 89.78 & 86.33 & 101.00 & 107.00 & 98.11 & 93.95 \\
\hline Mean & 71.42 & 82.75 & 88.83 & 81.00 & 79.08 & 92.25 & 94.42 & 88.58 & 84.79 \\
\hline $\begin{array}{lc}\text { LSD } & \mathbf{A} \\
& \text { B } \\
& \text { AB }\end{array}$ & & $\begin{array}{l}2 . \\
1 . \\
2 .\end{array}$ & & & & & $\begin{array}{l}2.63 \\
1.76 \\
3.52\end{array}$ & & \\
\hline
\end{tabular}

Table 8. Effect of different sources of nutrient and number of cutting on dry leaves: dry stem of stevia plant during 2014 and 2015 seasons.

\begin{tabular}{|c|c|c|c|c|c|c|c|c|c|}
\hline \multirow[t]{3}{*}{ Source of nutrient (A) } & \multicolumn{4}{|c|}{2014 season } & \multirow{2}{*}{\multicolumn{4}{|c|}{$\begin{array}{l}2015 \text { season } \\
\text { cutting (B) }\end{array}$}} & \multirow{3}{*}{$\begin{array}{c}\text { Overall } \\
\text { mean }\end{array}$} \\
\hline & \multicolumn{4}{|c|}{ Number of cutting (B) } & & & & & \\
\hline & $\begin{array}{c}1^{\text {st }} \\
\text { cutting }\end{array}$ & $\begin{array}{l}2^{\text {nd }} \\
\text { cutting }\end{array}$ & $\begin{array}{l}3^{\text {rd }} \\
\text { cutting }\end{array}$ & Mean & $\begin{array}{c}1^{\text {st }} \\
\text { cutting }\end{array}$ & $\begin{array}{l}2^{\text {nd }} \\
\text { cutting }\end{array}$ & \begin{tabular}{|l}
$3^{\text {rd }}$ cut- \\
ting
\end{tabular} & Mean & \\
\hline Control $\left(80 \mathrm{~kg} \mathrm{~N} \mathrm{fed}^{-1}\right)$ & 1.70 & 1.65 & 0.98 & 1.44 & 1.00 & 0.90 & 0.78 & 0.89 & 1.17 \\
\hline K-Humate+((50\%of cont.) & 1.78 & 1.71 & 1.02 & 1.51 & 1.03 & 0.93 & 0.79 & 0.91 & 1.21 \\
\hline Biofertilizer+(50\% of cont.) & 1.82 & 1.77 & 1.04 & 1.54 & 1.19 & 0.95 & 0.85 & 1.00 & 1.27 \\
\hline Compost $+(50 \%$ of cont. $)$ & 1.92 & 1.61 & 0.91 & 1.48 & 1.17 & 0.91 & 0.78 & 0.95 & 1.22 \\
\hline Mean & 1.81 & 1.68 & 0.99 & 1.49 & 1.09 & 0.92 & 0.85 & 1.08 & 1.28 \\
\hline $\begin{array}{lc}\text { LSD } & \mathbf{A} \\
& \text { B } \\
& \text { AB }\end{array}$ & \multicolumn{4}{|c|}{$\begin{array}{l}\mathrm{NS} \\
0.09 \\
\mathrm{NS}\end{array}$} & & & $\begin{array}{l}0.07 \\
0.08 \\
0.17\end{array}$ & & \\
\hline
\end{tabular}

Data tabulated in Tables (3-8) show the effect of number of cutting on plant height, fresh plant weight, dry plant weight, fresh leaves weight/plant, dry leaves weight/plant and dry leaves weight: dry stem weight of stevia rebaudiana. Results cleared that number of cutting had a significant effect on the all studied traits in two growing seasons. The present results revealed that increasing number of cutting from $1^{\text {st }}$ cutting to $2^{\text {nd }}$ and $3^{\text {rd }}$ cutting led to an increase in plant height from 48.26 to 55.68 and $68.33 \mathrm{~cm}$, fresh leaves weight/plant from 613.79 to 650.04 and $678.71 \mathrm{~g}$, dry leaves weight/plant from 214.13 to 230.67 and $252.79 \mathrm{~g}$, fresh leaves weight/plant from 235.71 to 255.00 and $261.76 \mathrm{~g}$,weight was decreased from 1.45 to 1.30 and 0.92 $\%$, as an average value of the two studies seasons, respectively. where there were a reverse relationship between number of cutting and dry leaves weight: dry stem weight dry. This decrease might be due to the increase in dry stem weight with progess number of cutting .This increase might be due to increasing number of cutting from 1 st cutting to 2nd and 3rd cutting led to improving the morphological characters and improved the root activity and enhanced the photosynthesis rate. These results are agreement with 
those found by Kumar, et al. (2012 and 2013).

A significant interaction was showed in Tables (3-8) between sources of nutrient $(A)$ and number of cutting (B) with regard toplant height, fresh plant weight, dryplant weight, fresh leaves weight/plant in both seasons and the $2^{\text {nd }}$ season for dry leaves weight: dry stem weight. It could be revealed from the results that application of compost $+50 \%$ of the control with $3^{\text {rd }}$ cutting scored the highest values of fresh plant weight, dry plant weight, fresh leaves weight/plantand dry leaves weight/plant of stevia. Such findings are in accordance with those found by Kumar, et al. (2013).

\section{II- Plant nutrient status:}

Data for the major nutrients in leaf of stevia such as N, P and k, affected by the different sources of nutrient are given in Tables 9-11. The present results revealed that sources of nutrient had a significantly effect on $\mathrm{N}, \mathrm{K}$ and $\mathrm{P} \%$ in stevia leaf. The lowest values of nitrogen, phosphorus and potassium contents $(1.50,0.19$ and $1.52 \%$,) were found with control $\left(80 \mathrm{~kg} \mathrm{~N} \mathrm{fed}^{-1}\right)$, while, compost + $50 \%$ of the control treatment scored the highest values $(1.63,0.28$ and $2.11 \%$ ), respectively. The aforementioned findings correlated with those recorded by Gupta, (2010); Gupta, et al. (2011); Khaled \& Fawy(2011) and Kumar, et al. (2012 and 2013) who reached the same results. In this subject, they revealed that increase in $\mathrm{K} \%$ of stevia leaf by compost application might be due to enhancement in $\mathrm{K}$ availability by shifting the equilibrium among the forms of $\mathrm{K}$ from relatively exchangeable $\mathrm{K}$ to soluble $\mathrm{K}$ forms in the soil. They added that K-humateis technically not a fertilizer, although in some walks people do consider it. K-humatemay enhance the uptake of some nutrient, reduce the uptake of toxic elements and improve the plant.

Table 9. Effect of different sources of nutrient and number of cutting on nitrogen content (\%) of fresh stevia plant during 2014 and 2015 seasons.

\begin{tabular}{|c|c|c|c|c|c|c|c|c|c|}
\hline \multirow{3}{*}{ Source of nutrient (A) } & \multicolumn{4}{|c|}{2014 season } & \multicolumn{4}{|c|}{2015 season } & \multirow[b]{3}{*}{$\begin{array}{c}\text { Overall } \\
\text { mean }\end{array}$} \\
\hline & \multicolumn{8}{|c|}{ Number of cutting (B) } & \\
\hline & $\begin{array}{c}1^{\text {st }} \\
\text { cutting }\end{array}$ & $\begin{array}{c}2^{\text {nd }} \\
\text { cutting }\end{array}$ & $\begin{array}{c}3^{\text {rd }} \\
\text { cutting }\end{array}$ & Mean & $\begin{array}{l}1^{\text {st }} \\
\text { cutting }\end{array}$ & $\begin{array}{c}2^{\text {nd }} \\
\text { cutting }\end{array}$ & $\begin{array}{c}3^{\text {rd }} \\
\text { cutting }\end{array}$ & Mean & \\
\hline Control $\left(80 \mathrm{~kg} \mathrm{~N}\right.$ fed $\left.^{-1}\right)$ & 1.44 & 1.50 & 1.52 & 1.48 & 1.47 & 1.53 & 1.58 & 1.52 & 1.50 \\
\hline K-Humate $+((50 \%$ of cont. $)$ & 1.46 & 1.50 & 1.55 & 1.50 & 1.50 & 1.55 & 1.59 & 1.54 & 1.52 \\
\hline $\begin{array}{l}\text { Biofertilizer }+(50 \% \text { of } \\
\text { cont.) }\end{array}$ & 1.62 & 1.55 & 1.56 & 1.58 & 1.68 & 1.57 & 1.64 & 1.63 & 1.60 \\
\hline Compost + (50\% of cont.) & 1.64 & 1.62 & 1.59 & 1.62 & 1.66 & 1.66 & 1.61 & 1.64 & 1.63 \\
\hline Mean & 1.54 & 1.54 & 1.56 & 1.55 & 1.60 & 1.58 & 1.60 & 1.59 & 1.57 \\
\hline $\begin{array}{cc}\text { LSD } & \text { A } \\
& \text { B } \\
& \text { AB }\end{array}$ & & $\begin{array}{l}0.0 \\
\mathrm{~N} \\
\mathrm{~N}\end{array}$ & & & & & $\begin{array}{l}0.07 \\
\text { NS } \\
\text { NS }\end{array}$ & & \\
\hline
\end{tabular}


Table 10. Effect of different sources of nutrient and number of cutting on phosphorus content (\%) of fresh stevia plant during 2014 and 2015 seasons.

\begin{tabular}{|c|c|c|c|c|c|c|c|c|c|}
\hline \multirow{3}{*}{ Source of nutrient (A) } & \multicolumn{4}{|c|}{2014 season } & \multicolumn{4}{|c|}{2015 season } & \multirow[b]{3}{*}{$\begin{array}{c}\text { Overall } \\
\text { mean }\end{array}$} \\
\hline & \multicolumn{5}{|c|}{ Number of cutting } & \multicolumn{3}{|c|}{ (B) } & \\
\hline & $\begin{array}{c}1^{\text {st }} \\
\text { cutting }\end{array}$ & $\begin{array}{c}2^{\text {nd }} \\
\text { cutting }\end{array}$ & $\begin{array}{c}3^{\text {rd }} \\
\text { cutting }\end{array}$ & Mean & $\begin{array}{c}1^{\text {st }} \\
\text { cutting }\end{array}$ & $\begin{array}{c}\mathbf{2}^{\text {nd }} \\
\text { cutting }\end{array}$ & $\begin{array}{c}3^{\text {rd }} \\
\text { cutting }\end{array}$ & Mean & \\
\hline Control $\left(80 \mathrm{~kg} \mathrm{~N} \mathrm{fed}^{-1}\right)$ & 0.13 & 0.19 & 0.23 & 0.18 & 0.14 & 0.19 & 0.27 & 0.20 & 0.19 \\
\hline K-Humate $+((50 \%$ of cont. $)$ & 0.14 & 0.19 & 0.23 & 0.19 & 0.14 & 0.20 & 0.27 & 0.20 & 0.25 \\
\hline Biofertilizer+(50\% of cont.) & 0.13 & 0.20 & 0.26 & 0.20 & 0.13 & 0.23 & 0.30 & 0.22 & 0.26 \\
\hline Compost $+(50 \%$ of cont. $)$ & 0.13 & 0.19 & 0.23 & 0.18 & 0.14 & 0.24 & .032 & 0.23 & 0.28 \\
\hline Mean & 0.13 & 0.19 & 0.24 & 0.19 & 0.14 & 0.21 & 0.29 & 0.21 & 0.27 \\
\hline $\begin{array}{lc}\text { LSD } & \text { A } \\
& \text { B } \\
& \text { AB }\end{array}$ & & $\begin{array}{l}0.0 \\
0.0 \\
0.0\end{array}$ & & & & & $\begin{array}{l}0.01 \\
0.02 \\
0.04\end{array}$ & & \\
\hline
\end{tabular}

Table 11. Effect of different sources of nutrient and number of cutting on potassium content $(\%)$ of fresh stevia plant during 2014 and 2015 seasons.

\begin{tabular}{|c|c|c|c|c|c|c|c|c|c|}
\hline \multirow{3}{*}{ Source of nutrient(A) } & \multicolumn{4}{|c|}{2014 season } & \multicolumn{4}{|c|}{2015 season } & \multirow[b]{3}{*}{$\begin{array}{c}\text { Overall } \\
\text { mean }\end{array}$} \\
\hline & \multicolumn{5}{|c|}{ Number of cutting } & \multicolumn{3}{|c|}{ (B) } & \\
\hline & $\begin{array}{c}1^{\text {st }} \\
\text { cutting }\end{array}$ & $\begin{array}{c}2^{\text {nd }} \\
\text { cutting }\end{array}$ & $\begin{array}{c}3^{\text {rd }} \\
\text { cutting }\end{array}$ & Mean & $\begin{array}{c}1^{\text {st }} \\
\text { cutting }\end{array}$ & $\begin{array}{c}2^{\text {nd }} \\
\text { cutting }\end{array}$ & $\begin{array}{c}3^{\text {rd }} \\
\text { cutting }\end{array}$ & Mean & \\
\hline Control $\left(80 \mathrm{~kg} \mathrm{~N}\right.$ fed $\left.^{-1}\right)$ & 1.39 & 1.52 & 1.52 & 1.48 & 1.44 & 1.58 & 1.65 & 1.56 & 1.52 \\
\hline K-Humate $+((50 \%$ of cont. $)$ & 1.46 & 1.58 & 1.68 & 1.57 & 1.47 & 1.60 & 1.69 & 1.59 & 1.58 \\
\hline Biofertilizer $+(50 \%$ of cont. $)$ & 1.78 & 1.90 & 2.02 & 1.90 & 1.80 & 1.92 & 2.03 & 1.92 & 1.91 \\
\hline Compost $+(50 \%$ of cont. $)$ & 2.11 & 2.15 & 1.87 & 2.05 & 2.13 & 2.19 & 2.19 & 2.17 & 2.11 \\
\hline Mean & 1.77 & 1.79 & 1.68 & 1.75 & 1.71 & 1.82 & 1.89 & 1.81 & 1.78 \\
\hline $\begin{array}{lc}\text { LSD } & \text { A } \\
& \text { B } \\
& \text { AB }\end{array}$ & & & $\begin{array}{l}14 \\
\text { IS } \\
\text { IS }\end{array}$ & & & & $\begin{array}{l}0.05 \\
0.03 \\
0.06 \\
\end{array}$ & & \\
\hline
\end{tabular}

The results given in Tables (911) indicated the differences in $\mathrm{N} \%$ of stevia leaf did not reach the level of significance as affected by number of cutting. The present results revealed that number of cutting led to significant increase in $\mathrm{P}$ and $\mathrm{K} \%$ of stevia leaf in the $2^{\text {nd }}$ season only. Increasing number of cutting from $1^{\text {st }}$ cutting to $2^{\text {nd }}$ or $3^{\text {rd }}$ cutting led to increase in $\mathrm{P} \%$ of stevia leaf from 0.14 to 0.20 or $0.26 \%$ and $\mathrm{K} \%$ of stevia leaf from 1.74 to 1.81 or $1.79 \%$ ,as average value of the two studied seasons, respectively. This increase in might be due to improve the root activity and enhanced the $\mathrm{P}$ and $\mathrm{K}$ absorption from the soil. These results are agreement with those found by Kumar, et al. (2012 and 2013).

A significant interaction was scored in Tables (9-11) between sources of nutrient (A) and number of cutting (B) with regard to $\mathrm{P} \%$ of stevia leaf in both seasons and $\mathrm{K} \%$ of stevia leafin the $2^{\text {nd }}$ season. It could be revealed from the results that application of compost $+50 \%$ of the control with $2^{\text {nd }}$ or $3^{\text {rd }}$ cutting scored the highest value (0.32 and $2.19 \%)$ of $\mathrm{P}$ and $\mathrm{K} \%$ of stevia leaf. These findings are in the same line with those found by Rodriguez \& Fraga (1999) and Kumar, et al. (2013) who revealed that biofertilizer containg Bacillus megaterium and Azotobacterb chroococcum allows an increase in K supply to the plant.

\section{III- Yields of stevia rebaudiana :}

Leaves of stevia are the main economic part, hence production of more leaf biomass with higher steviol glycosides ( $\mathrm{St}$ and $\mathrm{Rb}$ ) is the main criterion for performance. The recorded results in this work 
(Tables,12-17) indicated that sources of nutrient had a highly significant effect on fresh biomass yield ( $\mathrm{kg} / \mathrm{fed})$, dry biomass yield ( $\mathrm{kg} / \mathrm{fed})$, fresh leaves yield $(\mathrm{kg} / \mathrm{fed})$, dry leaves yield $(\mathrm{kg} / \mathrm{fed})$ and fresh stem yield $(\mathrm{kg} / \mathrm{fed})$ of stevia, except dry stem yield $(\mathrm{kg} / \mathrm{fed})$ did not reach the level of significance in both seasons. It could be concluded from the results that the lowest values of fresh biomass yield $(10289 \mathrm{~kg} / \mathrm{fed})$, fresh leaves yield $(6139 \mathrm{~kg} / \mathrm{fed})$, dry leaves yield $(1971 \mathrm{~kg} / \mathrm{fed})$, fresh stem yield $(4146 \mathrm{~kg} / \mathrm{fed})$ as well as highest value of dry stem yield (1830 kg/fed) were found with K-Humateapplication, while, biofertilizer application scored the highest values of fresh biomass yield, dry biomass yield, fresh leaves yield and dry leaves yield of stevia $(10551 \mathrm{~kg} / \mathrm{fed}, \quad 3941.06 \mathrm{~kg} / \mathrm{fed}$, $6456 \mathrm{~kg} / \mathrm{fed}$ and $2122 \mathrm{~kg} / \mathrm{fed}$ ), as well as the lowest value of fresh stem yield (4095 kg/fed) respectively,. The aforementioned findings correlated with those recorded by Rodriguez \&
Fraga (1999) ;Gupta, (2010) ;Gupta, et al. (2011) and Kumar, et al. (2012, 2013 and 2014) who revealed that application of biofertilizer improved the root activity and enhanced the photosynthesis, finally the biomass of stevia was increased. They added that this increase might be due to bacterial inoculation may be attributed to their effect on nitrogen fixation. They indicated that stevia is many time sweetener than sugar cane and sugar beet and becomes an inevitable alternative to sugar, especially for the diabetic population of nearly 347 million across the world (WHO, 2013). Currently, stevia production is centered in China and the major market is Japan. In addition, they demonstrated that the principal mechanism for biofertilizer is the production of organic acids and acid phosphatases play a major role in the mineralization of organic phosphorous in soil.

Table 12. Effect of different sources of nutrient and number of cutting on fresh biomass yield (kg/ fed) of stevia plant during 2014 and 2015 seasons.

\begin{tabular}{|c|c|c|c|c|c|c|c|c|c|}
\hline \multirow{3}{*}{ Source of nutrient (A) } & \multicolumn{5}{|c|}{2014 season } & \multicolumn{3}{|c|}{2015 season } & \multirow{3}{*}{$\begin{array}{c}\text { Overall } \\
\text { mean }\end{array}$} \\
\hline & \multicolumn{8}{|c|}{ Number of cutting (B) } & \\
\hline & $\begin{array}{c}\text { 1st } \\
\text { cutting }\end{array}$ & $\begin{array}{c}\text { 2nd } \\
\text { cutting }\end{array}$ & $\begin{array}{c}\text { 3rd } \\
\text { cutting }\end{array}$ & Mean & $\begin{array}{c}\text { 1st } \\
\text { cutting }\end{array}$ & $\begin{array}{c}\text { 2nd } \\
\text { cutting }\end{array}$ & $\begin{array}{c}\text { 3rd } \\
\text { cutting }\end{array}$ & Mean & \\
\hline Control $\left(80 \mathrm{~kg} \mathrm{~N} \mathrm{fed}^{-1}\right)$ & 8903 & 10585 & 11999 & 10496 & 8770 & 9843 & 11630 & 10081 & 10289 \\
\hline K-Humate $+(50 \%$ of cont. $)$ & 9169 & 10581 & 11320 & 10356 & 8861 & 10475 & 11569 & 10302 & 10329 \\
\hline Biofertilizer $+(50 \%$ of cont. $)$ & 9609 & 11368 & 11982 & 10986 & 8248 & 9426 & 10922 & 9532 & 10259 \\
\hline Compost $+50 \%$ of cont.) & 9682 & 11279 & 12323 & 11095 & 8423 & 10050 & 11550 & 10007 & 10551 \\
\hline Mean & 9340 & 10953 & 11906 & 10733 & 8576 & 9949 & 11418 & 9981 & 10357 \\
\hline $\begin{array}{llc}\text { LSD } & \mathbf{A} & \\
& & \mathbf{B} \\
& & \mathbf{A B}\end{array}$ & & $\begin{array}{r}388 \\
339 \\
\mathrm{~N}\end{array}$ & & & & & $\begin{array}{l}428.63 \\
317.25 \\
\text { NS }\end{array}$ & & \\
\hline
\end{tabular}


Table 13. Effect of different sources of nutrient and number of cutting on dry biomass yield(kg /fed) of fresh stevia plant during 2014 and 2015 seasons.

\begin{tabular}{|c|c|c|c|c|c|c|c|c|c|}
\hline \multirow{3}{*}{ Source of nutrient(A) } & \multicolumn{4}{|c|}{2014 season } & \multicolumn{4}{|c|}{2015 season } & \multirow{3}{*}{$\begin{array}{r}\text { Overal } \\
\text { mean }\end{array}$} \\
\hline & \multicolumn{8}{|c|}{ Number of cutting (B) } & \\
\hline & $\begin{array}{c}1^{\text {st }} \\
\text { cutting }\end{array}$ & $\begin{array}{c}2^{\text {nd }} \\
\text { cutting }\end{array}$ & $\begin{array}{c}3^{\text {rd }} \\
\text { cutting }\end{array}$ & Mean & $\begin{array}{c}1^{\text {st }} \\
\text { cutting }\end{array}$ & $\begin{array}{c}2^{\text {nd }} \\
\text { cutting }\end{array}$ & $\begin{array}{c}3^{\text {rd }} \\
\text { cutting }\end{array}$ & Mean & \\
\hline Control $\left(80 \mathrm{~kg} \mathrm{~N} \mathrm{fed}^{-1}\right)$ & 2970 & 3102 & 4253 & 3442 & 2994 & 3122 & 4279 & 3465 & 3453 \\
\hline K-Humate+(50\% of cont.) & 3079 & 3215 & 4364 & 3552 & 3552 & 4049 & 4720 & 4107 & 3830 \\
\hline Biofertilizer+(50\%of cont.) & 3076 & 3420 & 4313 & 3603 & 3395 & 3904 & 4467 & 3975 & 3789 \\
\hline Compost $+50 \%$ of cont.) & 32560 & 3560 & 4541 & 3787 & 3493 & 4055 & 4737 & 4095 & 3941 \\
\hline Mean & 3096 & 3324 & 4368 & 3596 & 3480 & 4003 & 4641 & 3897 & 3747 \\
\hline $\begin{array}{cc}\text { LSD } & \mathbf{A} \\
& \text { B } \\
& \text { AB }\end{array}$ & & & $\begin{array}{l}.64 \\
4.44 \\
\text { IS }\end{array}$ & & & & $\begin{array}{c}163.43 \\
129.17 \\
\text { NS }\end{array}$ & & \\
\hline
\end{tabular}

Table 14. Effect of different sources of nutrient and number of cutting on fresh leaves weight(kg/fed) of fresh stevia plant during 2014 and 2015 seasons.

\begin{tabular}{|c|c|c|c|c|c|c|c|c|c|}
\hline \multirow{3}{*}{ Source of nutrient (A) } & \multicolumn{4}{|c|}{2014 season } & \multicolumn{4}{|c|}{2015 season } & \multirow{3}{*}{$\begin{array}{c}\text { Overall } \\
\text { mean }\end{array}$} \\
\hline & \multicolumn{8}{|c|}{ Number of cutting (B) } & \\
\hline & $\begin{array}{c}1^{\text {st }} \\
\text { cutting }\end{array}$ & $\begin{array}{c}2^{\text {nd }} \\
\text { cutting }\end{array}$ & $\begin{array}{c}3^{\text {rd }} \\
\text { cutting }\end{array}$ & Mean & $\begin{array}{c}1^{\text {st }} \\
\text { cutting }\end{array}$ & $\begin{array}{c}2^{\text {nd }} \\
\text { cutting }\end{array}$ & $\begin{array}{c}3^{\text {rd }} \\
\text { cutting }\end{array}$ & Mean & \\
\hline Control $\left(80 \mathrm{~kg} \mathrm{~N}\right.$ fed $\left.^{-1}\right)$ & 6524 & 6876 & 7142 & 6847 & 5006 & 5352 & 5933 & 5430 & 6139 \\
\hline K-Humate $+(50 \%$ of cont. $)$ & 5866 & 6929 & 7311 & 6702 & 4958 & 5530 & 6259 & 5582 & 6142 \\
\hline Biofertilizer+(50\%of cont.) & 6467 & 7049 & 7578 & 7031 & 5066 & 5871 & 6707 & 5881 & 6456 \\
\hline Compost $+50 \%$ of cont.) & 5993 & 7097 & 7052 & 6714 & 6010 & 7106 & 7073 & 6730 & 6722 \\
\hline Mean & 6213 & 6988 & 7271 & 6824 & 5260 & 5965 & 6493 & 5631 & 6228 \\
\hline $\begin{array}{lc}\text { LSD } & \mathbf{A} \\
& \mathbf{B} \\
& \mathbf{A B}\end{array}$ & & $\begin{array}{r}32 \\
\mathrm{~N}\end{array}$ & & & & & $\begin{array}{c}283.20 \\
298.02 \\
\text { NS }\end{array}$ & & \\
\hline
\end{tabular}

Table 15. Effect of different sources of nutrient and number of cutting on dry leaves weight $(\mathrm{kg} /$ fed) of fresh stevia plant during 2014 and 2015 seasons.

\begin{tabular}{|c|c|c|c|c|c|c|c|c|c|}
\hline \multirow{3}{*}{$\begin{array}{l}\text { Source of nutrient } \\
\text { (A) }\end{array}$} & \multicolumn{4}{|c|}{2014 season } & \multicolumn{4}{|c|}{2015 season } & \multirow[b]{3}{*}{$\begin{array}{c}\text { Overall } \\
\text { mean }\end{array}$} \\
\hline & \multicolumn{8}{|c|}{ Number of cutting (B) } & \\
\hline & $\begin{array}{c}1^{\text {st }} \\
\text { cutting }\end{array}$ & \begin{tabular}{|c|}
$2^{\text {nd }}$ \\
cutting
\end{tabular} & $\begin{array}{c}3^{\text {rd }} \\
\text { cutting }\end{array}$ & Mean & $\begin{array}{c}1^{\text {st }} \\
\text { cutting }\end{array}$ & $\begin{array}{c}2^{\text {nd }} \\
\text { cutting }\end{array}$ & $\begin{array}{c}3^{\text {rd }} \\
\text { cutting }\end{array}$ & Mean & \\
\hline Control $\left(80 \mathrm{~kg} \mathrm{~N} \mathrm{fed}^{-1}\right)$ & 1868 & 1925 & 2102 & 1965 & 1881 & 1935 & 2118 & 1978 & 1971 \\
\hline K-Humate+(50\%of cont.) & 1968 & 2025 & 2202 & 2065 & 1778 & 1945 & 2081 & 1935 & 2000 \\
\hline Biofertilizer+(50\% of cont.) & 2020 & 2105 & 2057 & 2061 & 1803 & 1860 & 1963 & 1876 & 1969 \\
\hline Compost $+50 \%$ of cont.) & 2103 & 2272 & 2310 & 2228 & 1894 & 1971 & 2180 & 2015 & 2122 \\
\hline Mean & 1990 & 2082 & 2168 & 2080 & 1839 & 1928 & 2086 & 1951 & 2030 \\
\hline $\begin{array}{c}\text { LSD A } \\
\text { B } \\
\text { AB }\end{array}$ & \multicolumn{4}{|c|}{42.13} & & & $\begin{array}{c}56.95 \\
67 \\
\text { NS }\end{array}$ & & \\
\hline
\end{tabular}


Table 16. Effect of different sources of nutrient and number of cutting on fresh stemyield (kg/fed) of stevia plant during 2014 and 2015 seasons.

\begin{tabular}{|c|c|c|c|c|c|c|c|c|c|}
\hline \multirow{3}{*}{ Source of nutrient (A) } & \multicolumn{4}{|c|}{2014 season } & \multicolumn{4}{|c|}{2015 season } & \multirow{3}{*}{$\begin{array}{c}\text { Overall } \\
\text { mean }\end{array}$} \\
\hline & \multicolumn{8}{|c|}{ Number of cutting (B) } & \\
\hline & $\begin{array}{c}1^{\text {st }} \\
\text { cutting }\end{array}$ & $\begin{array}{c}2^{\text {nd }} \\
\text { cutting }\end{array}$ & $\begin{array}{c}3^{\text {rd }} \\
\text { cutting }\end{array}$ & Mean & $\begin{array}{c}1^{\text {st }} \\
\text { cutting }\end{array}$ & $\begin{array}{c}2^{\text {nd }} \\
\text { cutting }\end{array}$ & $\begin{array}{c}3^{\text {rd }} \\
\text { cutting }\end{array}$ & Mean & \\
\hline Control $\left(80 \mathrm{~kg} \mathrm{~N}\right.$ fed $\left.^{-1}\right)$ & 2837 & 3356 & 4488 & 3561 & 2851 & 3369 & 4495 & 3572 & 3566 \\
\hline K-Humate+(50\% of cont.) & 3037 & 3656 & 4689 & 3794 & 3813 & 4312 & 5371 & 4499 & 4146 \\
\hline Biofertilizer $+(50 \%$ of cont. $)$ & 3216 & 4230 & 4745 & 4063 & 3357 & 4179 & 4843 & 4126 & 4095 \\
\hline Compost $+50 \%$ of cont.) & 3084 & 4493 & 4840 & 4139 & 3242 & 4074 & 4988 & 4101 & 4120 \\
\hline Mean & 3044 & 3934 & 4690 & 3889 & 3316 & 3983 & 4924 & 4075 & 3982 \\
\hline LSD A & \multirow{2}{*}{\multicolumn{4}{|c|}{$\begin{array}{l}179.16 \\
16345\end{array}$}} & \multicolumn{5}{|c|}{208} \\
\hline B & & & & & \multicolumn{5}{|c|}{114} \\
\hline $\mathbf{A B}$ & \multicolumn{4}{|c|}{$\begin{array}{l}163.45 \\
326.90\end{array}$} & \multicolumn{5}{|c|}{ NS } \\
\hline
\end{tabular}

Table 17. Effect of different sources of nutrient and number of cutting on dry stemweight (kg/fed) of stevia plant during 2014 and 2015 seasons.

\begin{tabular}{|c|c|c|c|c|c|c|c|c|c|}
\hline \multirow{3}{*}{ Source of nutrient(A) } & \multicolumn{4}{|c|}{2014 season } & \multicolumn{4}{|c|}{2015 season } & \multirow{3}{*}{$\begin{array}{c}\text { Overall } \\
\text { mean }\end{array}$} \\
\hline & \multicolumn{8}{|c|}{ Number of cutting (B) } & \\
\hline & $\begin{array}{c}1^{\text {st }} \\
\text { cutting }\end{array}$ & $\begin{array}{c}2^{\text {nd }} \\
\text { cutting }\end{array}$ & $\begin{array}{c}3^{\text {rd }} \\
\text { cutting }\end{array}$ & Mean & $\begin{array}{c}1^{\text {st }} \\
\text { cutting }\end{array}$ & $\begin{array}{c}2^{\text {nd }} \\
\text { cutting }\end{array}$ & $\begin{array}{c}3^{\text {rd }} \\
\text { cutting }\end{array}$ & Mean & \\
\hline Control $\left(80 \mathrm{~kg} \mathrm{~N} \mathrm{fed}^{-1}\right)$ & 1103 & 1177 & 2150 & 1477 & 1113 & 1187 & 2160 & 1487 & 1482 \\
\hline K-Humate $+(50 \%$ of cont. $)$ & 1111 & 1189 & 2162 & 1487 & 1774 & 2104 & 2639 & 2172 & 1830 \\
\hline Biofertilizer $+(50 \%$ of cont. $)$ & 1055 & 1315 & 2256 & 1542 & 1592 & 2044 & 2504 & 2046 & 1794 \\
\hline Compost $+50 \%$ of cont.) & 1157 & 1288 & 2231 & 1559 & 1599 & 2084 & 2557 & 2080 & 1820 \\
\hline Mean & 1107 & 1243 & 2200 & 1516 & 1655 & 2077 & 2566 & 1946 & 1731 \\
\hline \begin{tabular}{|r|} 
LSD A \\
$\mathbf{B}$ \\
AB
\end{tabular} & & $\begin{array}{l}\mathrm{N} \\
1 \\
\mathrm{~N}\end{array}$ & & & & & $\begin{array}{l}122 \\
110 \\
221\end{array}$ & & \\
\hline
\end{tabular}

The data in Tables, (12-17) indicated that number of cutting had a highly significant effect on fresh biomass yield, dry biomass yield, fresh leaves yield, dry leaves yield and fresh stem yield and dry stem yield of stevia in both seasons. It could be concluded from the results that increasing number of cutting from $1^{\text {st }}$ cutting to $2^{\text {nd }}$ and $3^{\text {rd }}$ cutting led to increase in fresh biomass yield from 8939.28 to 10425.00 and $11734.22 \mathrm{~kg} / \mathrm{fed}$, dry biomass yield from 3309.00 to 3750.00 and 4523.72 $\mathrm{kg} / \mathrm{fed}$, fresh leaves yield from 5647.83 to 6267.95 and 6821.67 $\mathrm{kg} /$ fed, dry leaves yield from 1927.67 to 2029.72 and $2132.33 \mathrm{~kg} / \mathrm{fed}$ and fresh stem yield from 3291.44 to 4157.28 and $4912.56 \mathrm{~kg} / \mathrm{fed}$ and dry stem yield of stevia from 1381.33 to 1720.83 and $2391.39 \mathrm{~kg} / \mathrm{fed}$, as average value of the two studied seasons, respectively. This increase in might be due to improve the root activity, which led to increasing the yields of leaves and stem. These results are agreement with those found by Das, et al. (2007).

A significant interaction was scored in Tables (12-17) between sources of nutrient (A) and number of cutting (B) with regard to fresh biomass yield, dry biomass yield, fresh leaves yield and fresh stem yield of stevia in both seasons, except fresh biomass yield in the $2^{\text {nd }}$ season and fresh leaves yield of stevia in the 1 st season. It could be revealed from the results that application of compost with $3^{\text {rd }}$ cutting given the highest value of dry stevia leaf yield (2180.67 $\mathrm{kg} / \mathrm{fed}$ ). These results are in good accordance with those reported by Das, et al. (2007).

IV-Quality parameters of stevia : 
Production of more dry leaf biomass with higher steviol glycosides ( $\mathrm{St}$ and $\mathrm{Rb}$ ) is the main criterion for performance. The present results in this work (Tables,18-21) clarified that sources of nutrient had a highly significant effect on total stevioside \% (St \%), rebaudioside $\mathrm{A} \% \quad(\mathrm{Rb} \%)$, total stevioside yield $(\mathrm{kg} / \mathrm{fed})$ and rebaudioside A yield ( $\mathrm{kg} / \mathrm{fed})$ in both seasons of stevia. It could be concluded from the results that the lowest values of total stevioside (9.63\%), rebaudioside $\mathrm{A}(4.51 \%)$, total stevioside yield $(192.50 \mathrm{~kg} / \mathrm{fed})$ and rebaudioside A yield $\mathbf{( 9 0 . 2 6}$ $\mathrm{kg} / \mathrm{fed}$ ) were found with $\mathrm{K}$ Humateapplication, while, compost treatment scored the highest values $(10.63 \%, 5.23 \%, 208.95 \mathrm{~kg} / \mathrm{fed}$ and $102.80 \mathrm{~kg} / \mathrm{fed}$ ), respectively. The aforementioned findings correlated with those recorded by Kumar, et al. (2012, 2013 and 2014) who reached glycoside content in stevia was greater in those plants which was supplied with compost due to improve root activity. They added that $\mathrm{Rb}$ is responsible for sweetness in stevia leaves, so higher $\mathrm{Rb}$ is desirable. Stevia crop give economically viable yield up to $4-5$ years.

Table 18. Effect of different sources of nutrient and number of cutting on Stevioside \% of dry stevia leavesduring 2014 and 2015 seasons.

\begin{tabular}{|c|c|c|c|c|c|c|c|c|c|}
\hline \multirow{3}{*}{$\begin{array}{r}\text { Source of nutrient } \\
\text { (A) }\end{array}$} & \multicolumn{4}{|c|}{2014 season } & \multicolumn{4}{|c|}{2015 season } & \multirow{3}{*}{$\begin{array}{c}\text { Overal } \\
\text { mean }\end{array}$} \\
\hline & \multicolumn{4}{|c|}{ Number of cutting } & \multicolumn{4}{|c|}{ (B) } & \\
\hline & $\begin{array}{c}1^{\text {st }} \\
\text { cutting }\end{array}$ & $\begin{array}{l}2^{\text {nd }} \\
\text { cut- } \\
\text { ting }\end{array}$ & $\begin{array}{l}3^{\text {rd }} \\
\text { cut- } \\
\text { ting }\end{array}$ & Mean & $\begin{array}{c}1^{\text {st }} \\
\text { cutting }\end{array}$ & $\begin{array}{l}2^{\text {nd }} \\
\text { cut- } \\
\text { ting }\end{array}$ & $\begin{array}{l}3^{\text {rd }} \\
\text { cut- } \\
\text { ting }\end{array}$ & Mean & \\
\hline Control $\left(80 \mathrm{~kg} \mathrm{~N} \mathrm{fed}^{-1}\right)$ & 9.03 & 8.93 & 9.13 & 9.03 & 9.57 & 9.37 & 9.53 & 9.49 & 9.26 \\
\hline K-Humate+(50\%of cont. $)$ & 9.23 & 9.17 & 9.50 & 9.30 & 9.87 & 9.93 & 10.10 & 9.97 & 9.64 \\
\hline Biofertilizer $+(50 \%$ of cont. $)$ & 9.40 & 9.53 & 9.87 & 9.60 & 9.90 & 10.27 & 10.20 & 10.12 & 9.86 \\
\hline Compost $+50 \%$ of cont.) & 10.10 & 10.30 & 10.60 & 10.33 & 10.63 & 10.93 & 11.20 & 10.92 & 10.63 \\
\hline Mean & 9.44 & 9.48 & 9.78 & 9.57 & 9.99 & 10.13 & 10.26 & 10.13 & 9.85 \\
\hline $\begin{array}{lc}\text { LSD } & \mathbf{A} \\
& \mathbf{B} \\
& \mathbf{A B}\end{array}$ & & $\begin{array}{l}0 . \\
\mathrm{N} \\
\mathrm{N}\end{array}$ & & & & & $\begin{array}{l}0.26 \\
\text { NS } \\
\text { NS }\end{array}$ & & \\
\hline
\end{tabular}

Table 19. Effect of different sources of nutrient and number of cutting on rebaudiside $A \%$ of dry stevia leavesduring 2014 and 2015 seasons .

\begin{tabular}{|c|c|c|c|c|c|c|c|c|c|}
\hline \multirow{3}{*}{$\begin{array}{l}\text { Source of nutrient } \\
\text { (A) }\end{array}$} & \multicolumn{4}{|c|}{2014 season } & \multirow{2}{*}{\multicolumn{4}{|c|}{\begin{tabular}{|c}
2015 season \\
cutting (B)
\end{tabular}}} & \multirow[b]{3}{*}{$\begin{array}{c}\text { Overall } \\
\text { mean }\end{array}$} \\
\hline & \multicolumn{4}{|c|}{ Number of cutting (B) } & & & & & \\
\hline & $\begin{array}{c}1^{\text {st }} \\
\text { cutting }\end{array}$ & $\begin{array}{l}2^{\text {nd }} \\
\text { cut- } \\
\text { ting }\end{array}$ & $\begin{array}{c}3^{\text {rd }} \\
\text { cutting }\end{array}$ & Mean & $\begin{array}{c}1^{\text {st }} \\
\text { cutting }\end{array}$ & $\begin{array}{c}2^{\text {nd }} \\
\text { cutting }\end{array}$ & $\begin{array}{c}3^{\text {rd }} \\
\text { cutting }\end{array}$ & Mean & \\
\hline Control $\left(80 \mathrm{~kg} \mathrm{~N} \mathrm{fed}^{-1}\right)$ & 3.87 & 3.93 & 4.20 & 4.00 & 4.30 & 4.40 & 4.70 & 4.47 & 4.23 \\
\hline K-Humate $+(50 \%$ of cont. $)$ & 4.23 & 4.30 & 4.53 & 4.36 & 4.47 & 4.63 & 4.90 & 4.67 & 4.51 \\
\hline Biofertilizer $+(50 \%$ of cont. $)$ & 4.57 & 4.53 & 4.80 & 4.63 & 4.80 & 4.97 & 5.07 & 4.94 & 4.79 \\
\hline Compost $+50 \%$ of cont.) & 4.93 & 5.13 & 5.20 & 5.09 & 5.23 & 5.33 & 5.53 & 5.37 & 5.23 \\
\hline Mean & 4.40 & 4. 48 & 4.68 & 4.52 & 4.70 & 4.83 & 5.05 & 4.86 & 4.69 \\
\hline $\begin{array}{|lc|}\text { LSD } & \mathbf{A} \\
& \mathbf{B} \\
& \mathbf{A B} \\
\end{array}$ & \multicolumn{4}{|c|}{$\begin{array}{l}0.16 \\
0.32\end{array}$} & & & $\begin{array}{l}0.22 \\
0.14 \\
0.28\end{array}$ & & \\
\hline
\end{tabular}


Table 20. Effect of different sources of nutrient and number of cutting on stevioside yield kg/fed. of dry stevia leavesduring 2014 and 2015 seasons.

\begin{tabular}{|c|c|c|c|c|c|c|c|c|c|}
\hline \multirow{3}{*}{ Source of nutrient (A) } & \multicolumn{4}{|c|}{2014 season } & \multirow{2}{*}{\multicolumn{4}{|c|}{ cutting (B) }} & \multirow{3}{*}{$\begin{array}{l}\text { Overall } \\
\text { mean }\end{array}$} \\
\hline & \multicolumn{4}{|c|}{ Number of cutting (B) } & & & & & \\
\hline & $\begin{array}{c}1^{\text {st }} \\
\text { cutting }\end{array}$ & \begin{tabular}{|c|}
$2^{\text {nd }}$ \\
cutting
\end{tabular} & $\begin{array}{c}3^{\text {rd }} \\
\text { cutting }\end{array}$ & Mean & $\begin{array}{c}1^{\text {st }} \\
\text { cutting }\end{array}$ & $\begin{array}{c}2^{\text {nd }} \\
\text { cutting }\end{array}$ & $\begin{array}{c}3^{\text {rd }} \\
\text { cutting }\end{array}$ & Mean & \\
\hline Control $\left(80 \mathrm{~kg} \mathrm{~N} \mathrm{fed}^{-1}\right)$ & 168.53 & 171.82 & 192.01 & 177.46 & 179.92 & 181.05 & 201.96 & 187.64 & 182.55 \\
\hline K-Humate+(50\%of cont.) & 181.50 & 185.47 & 209.24 & 192.07 & 175.37 & 193.16 & 210.28 & 192.93 & 192.50 \\
\hline Biofertilizer $+(50 \%$ of cont. $)$ & 197.66 & 216.58 & 227.92 & 214.05 & 187.35 & 202.26 & 222.38 & 204.00 & 209.02 \\
\hline Compost $+50 \%$ of cont.) & 204.06 & 216.69 & 217.98 & 212.91 & 191.76 & 203.42 & 219.81 & 204.99 & 208.95 \\
\hline & 187.94 & 197.64 & 211.79 & 199.12 & 183.60 & 194.97 & 213.60 & 197.39 & 197.39 \\
\hline LSL & \multirow{3}{*}{\multicolumn{4}{|c|}{5.20}} & \multicolumn{5}{|c|}{7.83} \\
\hline 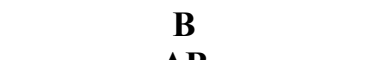 & & & & & \multirow{2}{*}{\multicolumn{5}{|c|}{$\begin{array}{c}5.95 \\
11.90\end{array}$}} \\
\hline $\mathbf{A B}$ & & & & 11.08 & & & & & \\
\hline
\end{tabular}

Table 21. Effect of different sources of nutrient and number of cutting on rebaudioside $A$ yield $\mathrm{kg} /$ fed of dry stevia leaves plant during 2014 and 2015 seasons .

\begin{tabular}{|c|c|c|c|c|c|c|c|c|c|}
\hline \multirow{3}{*}{$\begin{array}{l}\text { Source of nutrient } \\
\text { (A) }\end{array}$} & \multicolumn{4}{|c|}{2014 season } & \multicolumn{4}{|c|}{2015 season } & \multirow{3}{*}{$\begin{array}{c}\text { Overall } \\
\text { mean }\end{array}$} \\
\hline & \multicolumn{8}{|c|}{ Number of cutting (B) } & \\
\hline & $\begin{array}{c}1^{\text {st }} \\
\text { cutting }\end{array}$ & $\begin{array}{l}2^{\text {nd }} \\
\text { cut- } \\
\text { ting }\end{array}$ & $\begin{array}{l}3^{\text {rd }} \\
\text { cut- } \\
\text { ting }\end{array}$ & Mean & $\begin{array}{c}1^{\text {st }} \\
\text { cutting }\end{array}$ & $\begin{array}{l}2^{\text {nd }} \\
\text { cut- } \\
\text { ting }\end{array}$ & $\begin{array}{l}3^{\text {rd }} \\
\text { cut- } \\
\text { ting }\end{array}$ & Mean & \\
\hline Control $\left(80 \mathrm{~kg} \mathrm{~N}\right.$ fed $\left.^{-1}\right)$ & 72.15 & 75.80 & 88.30 & 78.75 & 80.78 & 85.27 & 99.57 & 88.54 & 83.64 \\
\hline K-Humate $+(50 \%$ of cont. $)$ & 83.19 & 87.08 & 99.85 & 90.04 & 79.47 & 90.11 & 101.89 & 90.49 & 90.27 \\
\hline Biofertilizer $+(50 \%$ of cont. $)$ & 96.02 & 102.98 & 110.88 & 103.29 & 90.87 & 97.76 & 110.45 & 99.69 & 101.49 \\
\hline Compost $+50 \%$ of cont.) & 99.70 & 108.02 & 106.90 & 104.87 & 94.38 & 99.25 & 108.56 & 100.73 & 102.80 \\
\hline Mean & 87.76 & 93.47 & 101.48 & 94.24 & 86.37 & 93.10 & 105.12 & 94.86 & 94.55 \\
\hline $\begin{array}{lc}\text { LSD } & \mathbf{A} \\
& \mathbf{B} \\
& \mathbf{A B}\end{array}$ & & $\begin{array}{l}4.9 \\
3.8 \\
7 .\end{array}$ & & & & & $\begin{array}{l}1.74 \\
3.56 \\
7.12\end{array}$ & & \\
\hline
\end{tabular}

In concern of number of cutting, data in Tables (18-21) revealed that increasing number of cutting from $1^{\text {st }}$ cutting to $2^{\text {nd }}$ and $3^{\text {rd }}$ cutting led to increase in total stevioside $\%$ from 9.86 to 10.2 and $10.25 \%$, rebaudioside $\mathrm{A} \%$ from 4.71 to 4.82 and $5.01 \%$, total stevioside yield (189.62 to 202.93 and $217.93 \mathrm{~kg} / \mathrm{fed})$ and rebaudioside A yield (90.61 to 97.53 and $106.97 \mathrm{~kg} / \mathrm{fed}$ ) of stevia as average value of the two studied seasons, respectively. These results are agreement with those found by Kumar, et al. (2013 and 2014) who indicated that production of leaf biomass along with higher steviol glycosides is the main criteria for technologist.

Significant interaction was scored in Tables (19-21) between sources of nutrient (A) and number of cutting (B) with regard to rebaudioside $\mathrm{A} \%$, total stevioside yield $(\mathrm{kg} / \mathrm{fed})$ and rebaudioside $\mathrm{A}$ yield $(\mathrm{kg} / \mathrm{fed})$ of stevia leaf in both seasons. It could be revealed from the results that application of compost with $3^{\text {rd }}$ cutting scored the highest values of total stevioside \%, rebaudioside $\mathrm{A} \%$, total stevioside yield $(\mathrm{kg} / \mathrm{fed})$ and rebaudioside $\mathrm{A}$ yield $(\mathrm{kg} / \mathrm{fed})$ of stevia leaf. Such data are in the same trend with those found by Kumar, et al. (2012). 
Chemical fertilizers are not only costly but also adversely affect the soil microbial population and are prohibited for the production of medicinal plants. Use of compost or biofertilizers has become imperative in medicinal plants to meet the nutrition demand of the crop. Compost provide a good substate for the growth of microorganisms and maintain a favorable nutrition balance and soil properties. Compost has a special place because of the presence of readily available plant nutritions, growth enhancing substances and number of beneficial microorganisms such as nitrogen (N)-fixing, Psolubility, potential to support the growth of microorganisms Kumar, et al. (2013).

In general, human health is greatly endangered as various complex diseases such as obesity and diabetes, developed in the last decade due to excessive intake of harmful sugars present in foods, beverages and in wide range of food prpducts. Stevioside is natural sweetener isolated from the leaves of plant stevia and it is up to 300 times sweetener than sucrose, where it is sweetener with no caloric value and with proven non-toxic effect on human health. steviol glycosides are used as a sweetener in many industrial foods, such as soft drinks or fruit juices (Dushyant, etal.2014).

From the present study, it may be concluded that the application either the biofertilizer or compost at 2.0 ton/fed was the best treatment for improving the yield and quality of stevia (Stevia rebaudiana Bertoni) with $3^{\text {rd }}$ cutting and is advisable because it is achieved the highest value of rebaudioside A (110.67 or $107.74 \mathrm{~kg} / \mathrm{fed})$. The use of biofertilizer or compost ineludible to minimise the environmental population, caused by the chemical ones. This helps in reducing the great gap in sugar production, which amounted to 0.7 million tons between production and sugar consumption at the national level production .

\section{Reference}

A.O.A.C (1995): Official Methods of Analysis Association of Official Agricultural Chemists 14th Benjamin Franklin Station, Washington D.C.U.S.A. pp. 49051.

Abdel-Malek, Y. and Y.Z. Ishac (1968): Evaluation of methods used in counting azotobacters. J. Appl. Bact., 31: 267-275.

Das, K.R. ; R.Dang ; T.N. Shivananda ; N.Sekerogla (2007): Influence of biofertilizer on the biomass yield and nutrient content in Stevia Rebaudiana Bert.grown in India subtropic. J. Medicinal plant research, 1(1): 5-8.

Das, K.R. ; R.Dang ; T.N. Shivananda ; N.Sekerogla (2009): Effect of biofertilizers on the nutrient avalability in soil in relation to growth, yield and yield attributes of Stevia Rebaudiana. Archives of Agronomy and soil Sci.,55:359366.

Dushyant, S.; S. Maji; S. Kumar; A.K. Maurya and K.R. Meena (2014): Efficacy of organic manures on growth, yield and biomolecules of stevia (Stevia Rebaudiana Bert.). J. Crop Weed, 10(1): 107-110.

Gomez, K.A. and Gomez, A.A (1984): Statistical procedures for Agriculture research. A WileyInter Science Publication, John Wiley and sons, Inc. New York, USA. 
Gupta ,M.; S.Bisht ; B.Singh; A. Gulati and R. Tewari (2011): Enhanced biomass and sreviol glycosides in stevia rebaudiana treated with phosphate solubility bacteria and rock phosphate. Plant Growth Regulation. 65:449-457.

Jackson, M.L. (1967): Soil chemical analysis. Prentice-Hall, Inc, Englewood Cliffs, NJ, USA.

Khaled, H. and H. Fawy (2011): Effect of different levels of K-Humateon the nutrient content, plant growth and soil properties under conditions of salinity. Soil \& Water Res. 6(1): 21-29.

Kumar, R.; S.Sharma ; K.Ramesh ; R. Prasad ; V.L.Pathania ; B. Singh and R.D.Singh (2012): Effect of agro-techniques on the performance of natural sweetener stevia (stevia rebaudiana) under Western Himalayan conditions. India J. Agronomy. 57:74-81.

Kumar, R.; S.Sharma and R. Prasad (2013): Yield, nutrient uptake and quaity of stevia as affected by organic sources of nutrient.
Communications in Soil Sci. and plant analysis. 44:3137-3149.

Kumar, R.; S.Sharma and S. Sood (2014): Yield components, high interception and marker compound accumulation of stevia (Stevia rebaudiana Bertoni) as affected by planting materials and plant density under Western Himalayan conditions. Archives of Agronomy and soil Sci., 10:1-15.

Patil, N.M.(2010): Biofertilizer effect on growth protein and carbohydrate contents in stevia Rebaudiana Var. Bertoni. Recent Research in Science and Technology, 2(10): 42-44.

Piper, C. S. (1950): "Soil and Plant Analysis". Inter Science Publisher Inc. New York.

Richards, L. A (1954): "Diagnosis and Improvement of saline and Alkaline soils".

Rodriguez, H and R. Fraga (1999): Phosphatesolubilizing bacteria and their role in plant growth promotion. Biotechnology Advances. 17: 319-339. 
تأثير استخدام هيومات البوتاسيوم ، الكمبوست والسماد الحيوى وايضا رقم الحشة

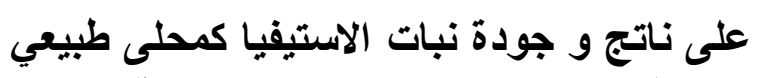

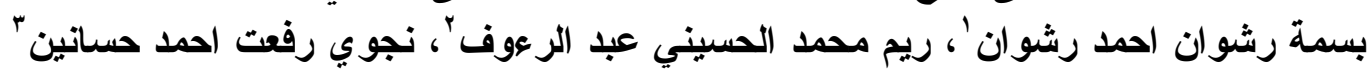

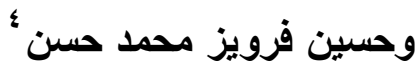

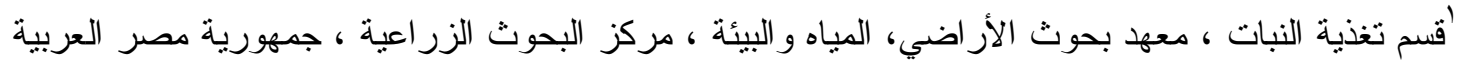

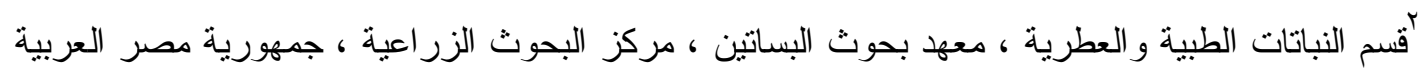

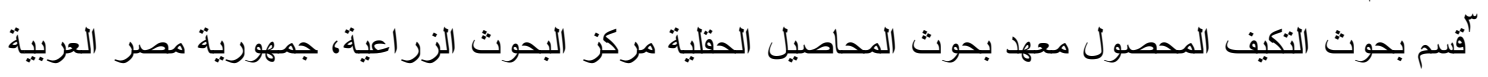

قُسم علوم وتكنولوجيا والاغذية ، كلية الزر اعة بالو ادي الجديد، جامعة اسيوط ، جمهورية مصر العربية.

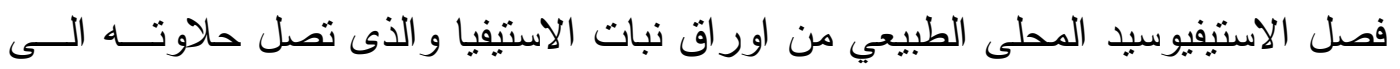

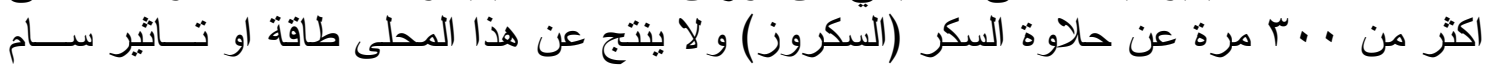

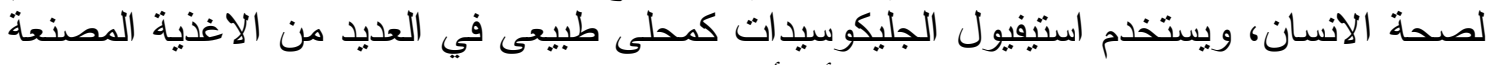

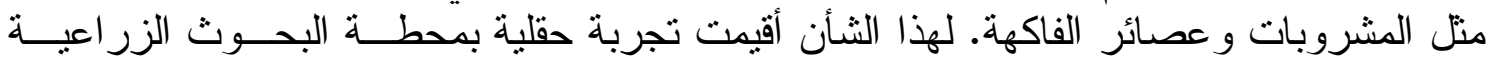

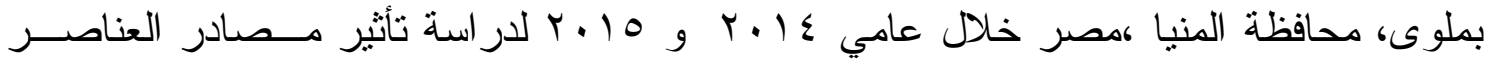

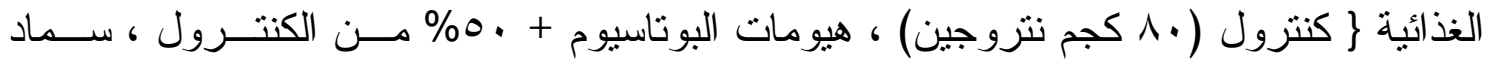

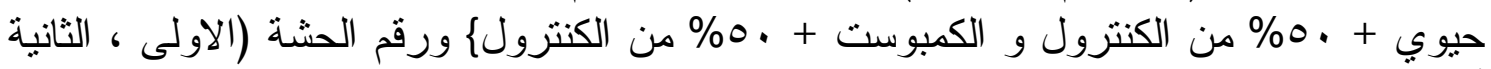
أو الثالثة) على ناتج وجودة هن هن منات الاستيفيا.

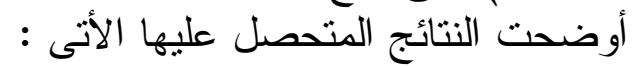

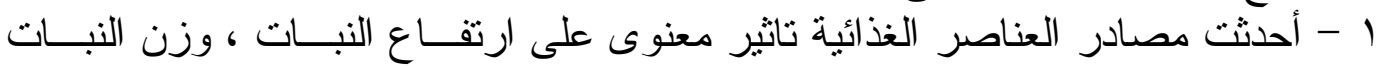

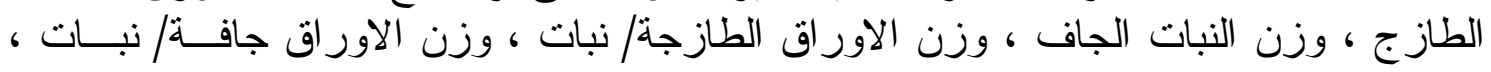

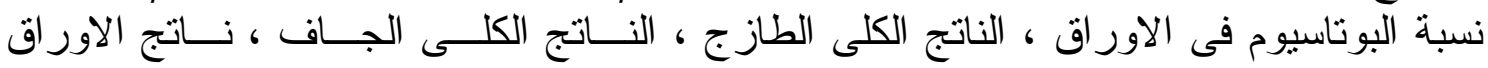

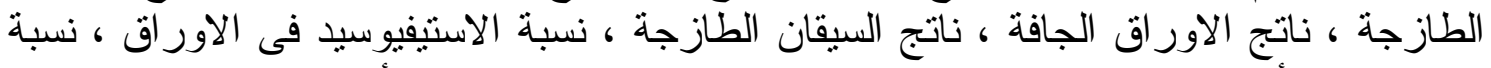

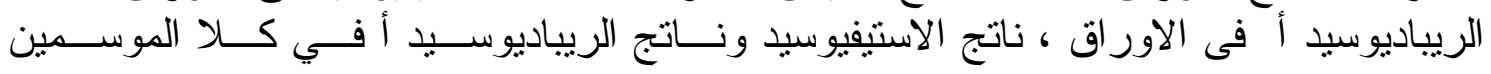

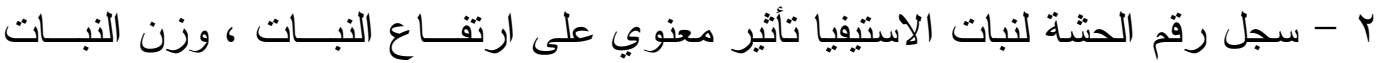

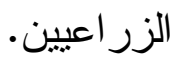

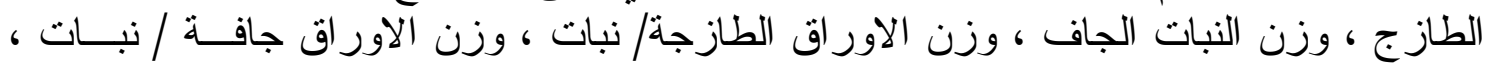

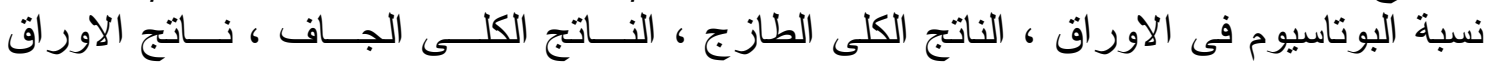

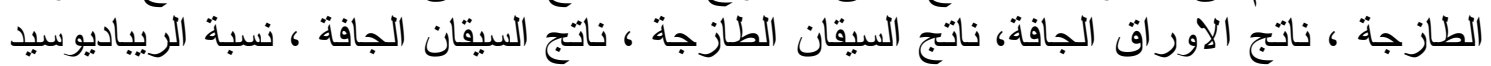

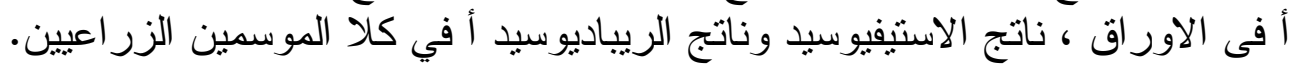

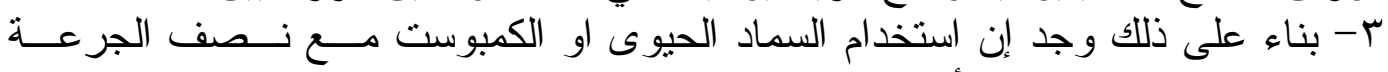

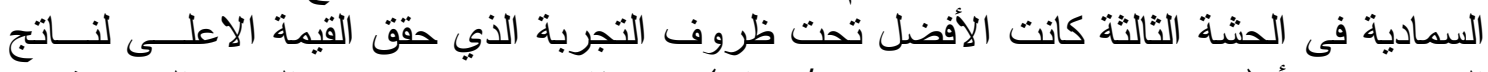

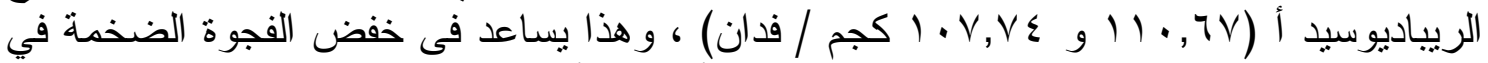

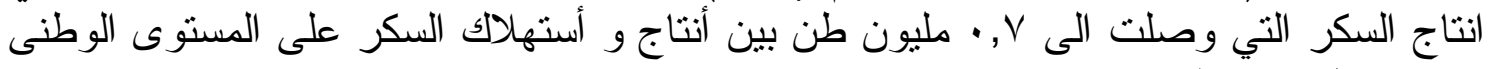

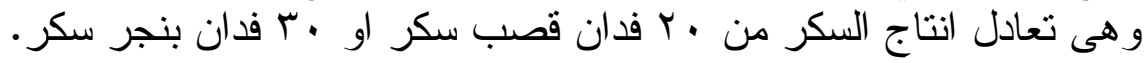

